\title{
Learning and development roles and competency domains in higher education: a content analysis of job announcements
}

\author{
Florence Martin ${ }^{1}$ (D) Yan Chen ${ }^{2} \cdot$ Beth Oyarzun $^{1} \cdot$ Mark Lee $^{3}$
}

Accepted: 16 July 2021 / Published online: 21 July 2021

(C) The Author(s), under exclusive licence to Springer Science+Business Media, LLC, part of Springer Nature 2021

\begin{abstract}
Learning and Development (L\&D) roles are important to organizations for improving employee's knowledge and skills. This study examined various roles and competency domains required of learning and development professionals in higher education. Ten different roles of L\&D professionals were examined for $20 \mathrm{com}-$ petency domains through a qualitative coding process. We extracted and analyzed 294 unique postings from the job board, higheredjobs.com. Results indicated that designers and directors are the most advertised L\&D postings. The top five competency domains required of L\&D professionals were collaboration, communication, content development, project management, and assessment and evaluation. Communication and collaboration skills were required for most of the roles. Leadership and people management were ranked highest for executives and directors. In addition, competency domains aggregated by roles are provided. Implications are provided for employees, L\&D graduate programs and professionals, and researchers.
\end{abstract}

Keywords Learning and development · Higher education · Roles · Competencies · Domains

Florence Martin

Florence.Martin@uncc.edu

Yan Chen

yanchen@unm.edu

Beth Oyarzun

Beth.Oyarzun@uncc.edu

Mark Lee

malee@csu.edu.au

1 Learning, Design and Technology, University of North Carolina Charlotte, 9201 University City Blvd, Charlotte, NC 28223, USA

2 University of New Mexico, Zimmerman Library Room 242, Albuquerque, NM 87131, USA

3 School of Education, Charles Sturt University, Wagga Wagga, NSW 2678, Australia 


\section{Introduction}

Learning and development (L\&D), a specialized human resources function, focuses on improving employee's knowledge and skills and thereby increasing an individual's job performance. The term "learning and development" can also be interchangeably referred to as training and development. The L\&D roles in higher education are usually affiliated with centers for teaching and learning involved with faculty development and human resource training that supports staff development. We chose to use the term "learning and development" since this is a broader term that encompasses various roles, including instructional designers.

\section{Learning and development focused professional organizations}

Several professional organizations focus on L\&D. Some of the organizations that primarily focus on L\&D competencies in corporate sectors with some resources for higher education include, Association for Talent Development (ATD), Learning and Performance Institute (LPI), International Society for Performance Improvement (ISPI), and Institute for Performance and Learning (I4PL). Each of these organizations has published competencies or skills for learning and development professionals. ATD (2014), formerly known as the American Society for Training and Development, included ten areas of expertise as essential for training and development which include, instructional design, training delivery, learning technologies, evaluating learning impact, managing learning programs, integrated talent management, coaching, knowledge management, change management and performance improvement. They also included six foundational competencies: business skills, global market, industry knowledge, interpersonal skills, personal skills, and technology literacy. The LPI based out of the United Kingdom provides a global view of the skills needed to deliver modern workplace learning and development by focusing on six capabilities: strategy and operations, design and development solutions, facilitating learning, performance and impact, and support learning (LPI, 2012). ISPI has ten standards they have included for performance consultants, and this includes, focus on results or outcomes, take a systemic view, add value, work in partnership with clients and stakeholders, determine need or opportunity, determine the cause, design solutions, including implementation and evaluation, ensure solutions', conformity and feasibility, implement solutions and evaluate results and impact. The Institutefor Performance and Learning Professionals (I4PL), formerly known as the Canadian Society for Training and Development (CSTD), has a competency framework for the L\&D professional focusing on assessing performance needs, designing curricula, designing learning experiences, facilitating learning, supporting the transfer of learning, and evaluating learning (I4PL, 2020). While each organization has some variations in its standards or competencies, there are commonalities such as designing and evaluating learning solutions.

Some of the other organizations that focus on L\&D competencies and standards for various sectors include the International Board of Standards for Training, Performance and Instruction (IBSTPI) and the Association for Educational 
Communications and Technology (AECT). IBSTPI (2012) has professional standards for instructional designers, training managers, and evaluators in addition to instructors and online learners. The instructional designer's standards focus on the following domains: professional foundations, planning and analysis, design and development, implementation and evaluation, and management. The training manager's standards focus on professional foundations, performance analysis and planning, design and development, and administration. The evaluator's standards focused on professional foundations, planning and designing an evaluation, implementing the evaluation plan, and managing the evaluation. The Association of Educational Communication Technologies (AECT) (2012) has proposed educational technologists' standards, including content knowledge, content pedagogy, learning environments, professional knowledge and skills, and research.

Additionally, some professional organizations focus specifically on higher education. The Online Learning Consortium (OLC) focuses specifically on the online and blended learning aspects of L\&D in higher education. Their five pillars of quality online education focus on learning effectiveness, scale, access, faculty satisfaction, and student satisfaction. Finally, the University Professional and Continuing Education Association (UPCEA) focuses on advancing online learning in postsecondary institutions. They promote seven standards to provide excellence in online learning leadership, and these include internal advocacy, entrepreneurial initiative, faculty support, student support, digital technology, external advocacy, and professionalism (Cavalier et al., n.d.). These organizations point to the need for the satisfaction and support of the major stakeholders in online learning, including faculty and students.

\section{Learning and development roles in higher education}

While several research studies have examined the instructional design and educational technology competencies in all sectors (Ritzhaupt \& Martin, 2014; Kang \& Ritzhaupt, 2015; McDonald \& Mayes, 2007; Wakefield et al., 2012; Williams Van Rooij, 2012), only a few research studies are focusing on the instructional design roles and competencies in higher education (Ritzhaupt \& Kumar, 2015; Sims \& Koszalka, 2008). Ritzhaupt and Kumar (2015) conducted in-depth interviews to study competencies for instructional designers in higher education and found that instructional designers needed a solid foundation in instructional design and learning theory, possess soft skills and technical skills and are willing to learn on the job. Chao et al. (2010) described the role of instructional designers in higher education as supporting faculty or subject matter experts in course design and providing the theoretical background in learning theory and instructional strategy. Similarly, McDonald and Mayes (2007) studied the role of an instructional designer at an Australian university where the designer was involved in interactions with the subject matter expert in the design of course and adoption of the pedagogical framework. The social constructivist principles were highlighted to engage and make it usable for them.

While instructional designers have been the focus of several studies, there have not been studies researching broadly at all levels of learning and development 
professionals including executives and directors or those in support positions such as assistants and associates to identify competencies for various L\&D roles. Sims and Koszalka (2008) expressed the need for instructional design competencies to be applied for various learners, instructors, and technical support staff rather than only focusing on the instructional designer. Richey and colleagues (2001) identified four roles in instructional design positions, including analyst, evaluator, elearning specialist, and project manager. Recently, learning engineers, learning architects, and learning experience designer positions have emerged which are related to the instructional design positions advertised (Jacobs, 2017; Lieberman, 2018). O' Keefe (2018) discusses the many hats that an instructional designer wears and elaborates that they need to perform several roles in situations where they are a one-member team or a part of a small team. In situations where there is a large team, the different roles can be differentiated, and each professional can focus on a smaller set of competencies.

\section{Learning and development competency domains in higher education}

Researchers refer to competency as a set of required knowledge, skills, attitudes, and abilities to be successful in a specific job performance setting (El Asame \& Wakrim, 2018; Richey et al., 2001; Ritzhaupt \& Martin, 2014). Contextualized in the landscape of higher education, the roles and responsibilities of learning and development professionals often reflect the changing academic culture and the evolving needs of the individual, group, and institution involved in this learning community (Blackmore, 2009). The L\&D professionals are often affiliated with programs such as the Center for Professional Development, Center for Teaching and Learning, Office of Faculty Affairs \& Faculty Development, Office of Faculty Development and Diversity, and Mentoring Institution. These programs provide training to develop both faculty and staff and lead and manage learning and teaching across the institution.

Intentional Future (2016) specified that the responsibilities of the majority of instructional designers in higher education fall into the four categories of designing digital materials for course delivery; managing the optimization of student learning outcomes through the efforts of administration, faculty, staff, and learning and development professionals such as instructional designers; training faculty and staff through effective implementation of technology and pedagogy; and supporting faculty and staff with the technical or instructional challenges during this learning and development process. As a result, it requires a set of competencies distinct from those in workplaces such as business and industry, consulting, and healthcare (Klein \& Kelly, 2018; Richey et al., 2001; Ritzhaupt \& Kumar, 2015). For example, Klein and Kelly (2018) identified five primary instructional design competencies in higher education: effective collaboration, knowledge of learning theory and principles, effective communication through multimodal approaches, and knowledge and experience with elearning-authoring software and learning management systems. Klein and Kelly further indicate that an emerging trend of learning and development professionals in higher education have been involved with the instructional technology category, which echoes the findings 
from both previous and recent research (Intentional Future, 2016; Richey et al., 2001; Ritzhaupt \& Kumar, 2015; Sugrue et al., 2018).

Additionally, researchers point out that the responsibility of L\&D for faculty and staff generally relies on the leadership and management positions in higher education (Marshall et al.,s, 2011; Mukherjee \& Singh, 1993). Marshall et al. argued that the key responsibilities of the leaders and managers of learning and teaching were to (1) promote institutional, faculty, and development culture, (2) develop individual faculty and their teaching practice, and (3) develop and maintain collaborative and collegial culture. However, although there has been a recent increase in the hiring of learning and development professionals in varied professional service sectors, only a few studies have focused on studying learning and development professionals, their affiliated leadership and management roles, or their relationship with the development of academic culture development in higher education (Sugrue et al., 2018).

\section{Purpose of this study}

While instructional design roles and competencies have been studied widely within all sectors (Klein \& Kelly, 2018; Kumar \& Ritzhaupt, 2017; Ritzhaupt et al., 2010), there is limited research on broadly studying roles and competencies for all learning and development professionals within higher education. In the present study, we explored all levels of learning and development roles situated in higher education and the competency domains each professional requires. By analyzing the range of postings, we hope to provide implications to programs in many areas, including educational leadership management and human resource development as applied to higher education. It also provides useful guidance for any L\&D related program (e.g. instructional design, educational technology) preparing graduates to serve in higher education roles. Through this effort, we aim to portray the many facets of the L\&D professionals' roles and competencies in higher education (Marshall et al., 2011). This study contributes to the existing literature by providing a content analysis of job announcements that extracts essential information pertaining to this specific research context in higher education.

\section{Research questions}

1. What L\&D roles are evident from the job announcements in higher education?

2. What L\&D competency domains are evident from the job announcements in higher education?

3. What education level and experience is required for learning and development professionals?

\section{Methods}

A systematic review and content analysis of job announcements were conducted to understand the roles of learning and development professionals in higher education. This section details the job announcement analysis methodology used in this study. 
Table 1 Job posting categories and selection

\begin{tabular}{lll}
\hline Job posting categories & $\begin{array}{l}\text { Number of jobs } \\
\text { posted }\end{array}$ & $\begin{array}{l}\text { Jobs used } \\
\text { in analysis }\end{array}$ \\
\hline Distance education & 49 & 32 \\
$\begin{array}{l}\text { Faculty development } \\
\begin{array}{l}\text { Instructional technology and } \\
\text { design }\end{array}\end{array}$ & 83 & 41 \\
$\quad$ Total & 452 & 221 \\
\hline
\end{tabular}

Table 2 Inclusion and exclusion

\begin{tabular}{lll}
\hline Criteria & Inclusion & Exclusion \\
\hline Focus of the job posting & $\begin{array}{c}\text { The job had to be } \\
\text { about Learning and } \\
\text { Development }\end{array}$ & Jobs that did not focus on Learning and Development \\
Publication date & $\begin{array}{c}\text { June and July 2019 } \\
\text { Only postings that } \\
\text { Complete posting } \\
\text { had sufficient }\end{array}$ & Prior to June 2019 and after July 2019 \\
& Postings that did not have sufficient information \\
& & \\
\hline
\end{tabular}

\section{Data collection}

Only a single job announcement board in higher education, higheredjobs.com was used in this study. Though there are a few other job boards for higher education, due to the high level of duplication in the job postings, only highredjobs.com was used. Three categories of job postings that were related to learning and development and posted across two months in June and July 2019 were compiled from higheredjobs.com. Table 1 includes the categories and number of jobs posted and used in this analysis.

While there were 452 postings initially, excluding duplicates and postings that did not fit our inclusion criteria, 294 jobs were identified for analysis. Table 2 includes the inclusion and exclusion criteria used to select the job announcements to be used in this analysis.

\section{Data coding procedures}

A total of 452 job postings were initially collected, but only 294 were included for the analysis. Job postings with incomplete information, duplicate postings, or those that did not meet our inclusion criteria were excluded. A systematic process was used for coding the job announcements. A coding form was created in Microsoft Excel and served as a tool to support the coding process for efficiency and accuracy.

The research team discussed the coding form, roles, and competency domains. The lead researcher coded five postings to test the form. The post-doctoral 
researcher and a faculty researcher individually coded half of the postings from among the reminder of the postings. The research team met once every three weeks to discuss questions during the coding process. The lead researcher coded $10 \%$ of the postings overlapping between both the coders. The interrater agreement was at $83.6 \%$

Based on recommendations for content analysis by Bengtsson (2016), the job postings were carefully examined for roles and competency domains. In addition to roles and competency domains, experience, education, location, and salary were also coded. Since salary information was not provided in most of the job postings, this was not further analyzed. The majority of the jobs were in the United States except for two postings in Canada.

Each job posting was given a unique identification number. Roles were grouped into ten categories, executive, director, manager, specialist, coordinator, designer, developer, technologist, associate/assistant, and other. Table 3 describes the L\&D roles in higher education and includes an example title.

Competency Domains were grouped into 20 categories, Strategic Planning, Front-end Analysis, Theories and Frameworks, Instructional Design, Content Development, Facilitate Training, Assessment and Evaluation, Mentoring and Coaching, Tech/Infrastructure Support, Leadership, and People Management, Project Management, Data Analytics, Faculty Development, Recruitment and Marketing, Communication, Collaboration, Student Support, Policy Development, Accreditation, Inclusiveness and Accessibility and other. Table 4 gives the description of each of these domains with examples.

\section{Data analysis}

Data was analyzed using Microsoft Excel and SPSS to compute frequencies and percentages for roles and competency domains. Data was sorted by roles and the total number of postings and percentages for each role were computed. Descriptive statistics, including the average number and standard deviation of postings by role, were also calculated. Frequencies and percentages were also computed and reported for competency domains, education requirements, experience, and location. Cross-tab analysis was conducted using SPSS to identify competency domain requirements and education level, and each role. The top five competency domain ranking by role was identified based on frequency.

\section{Results}

\section{Learning and development roles}

For the ten learning and development roles, frequencies and percentages are provided in Table 5. In addition, the average number and standard deviation of competency domains required for each role are included in Table 5. Based on the frequencies, designers were the most advertised role $(26.19 \%)$, followed by director 


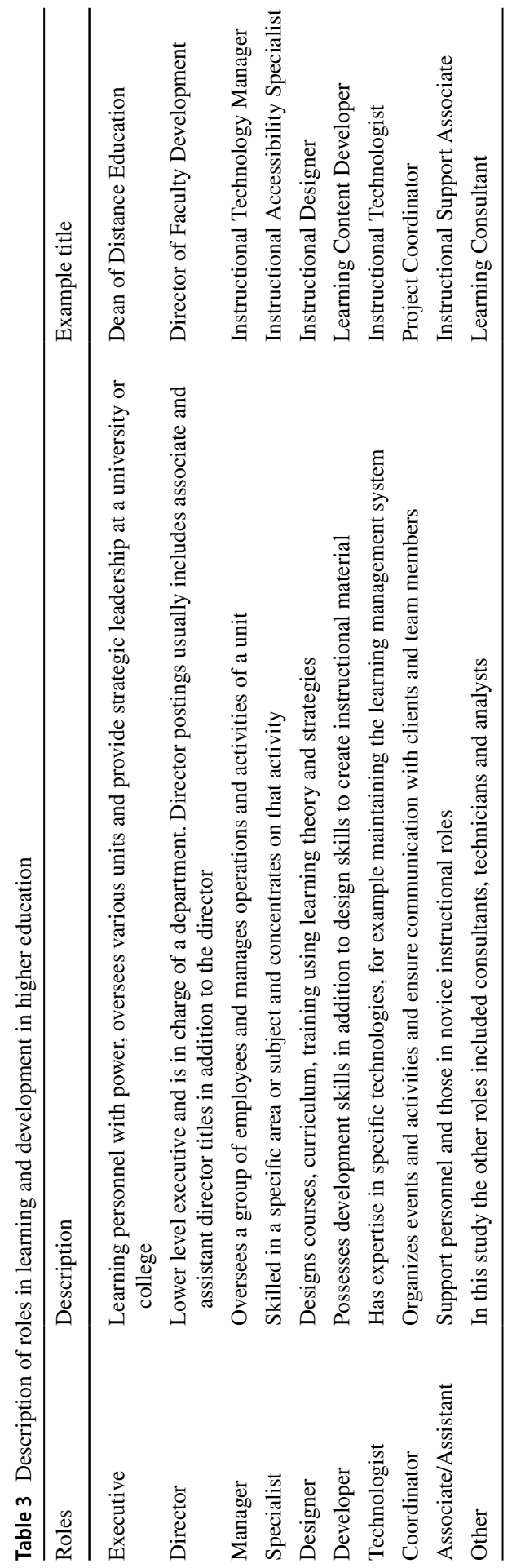




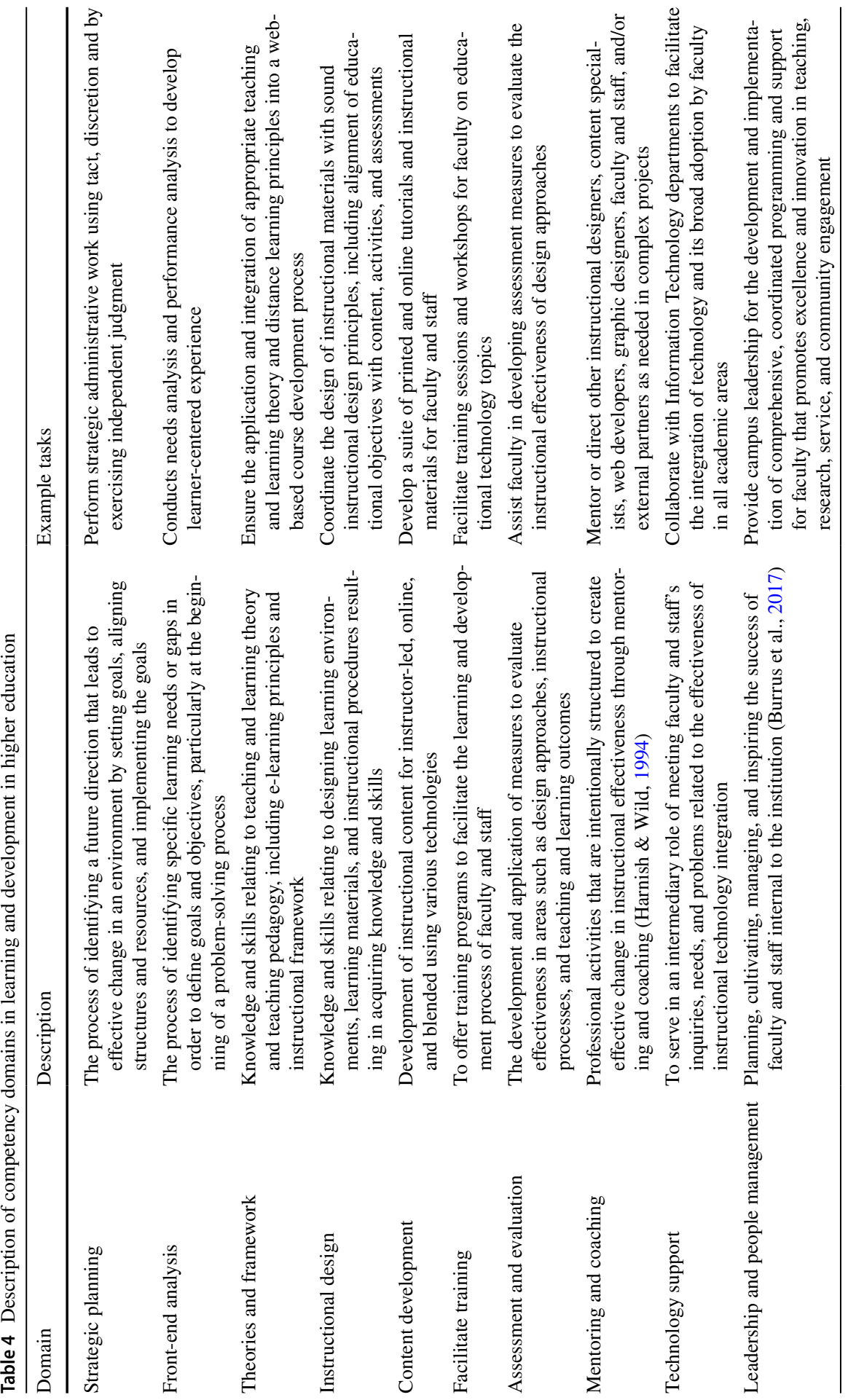




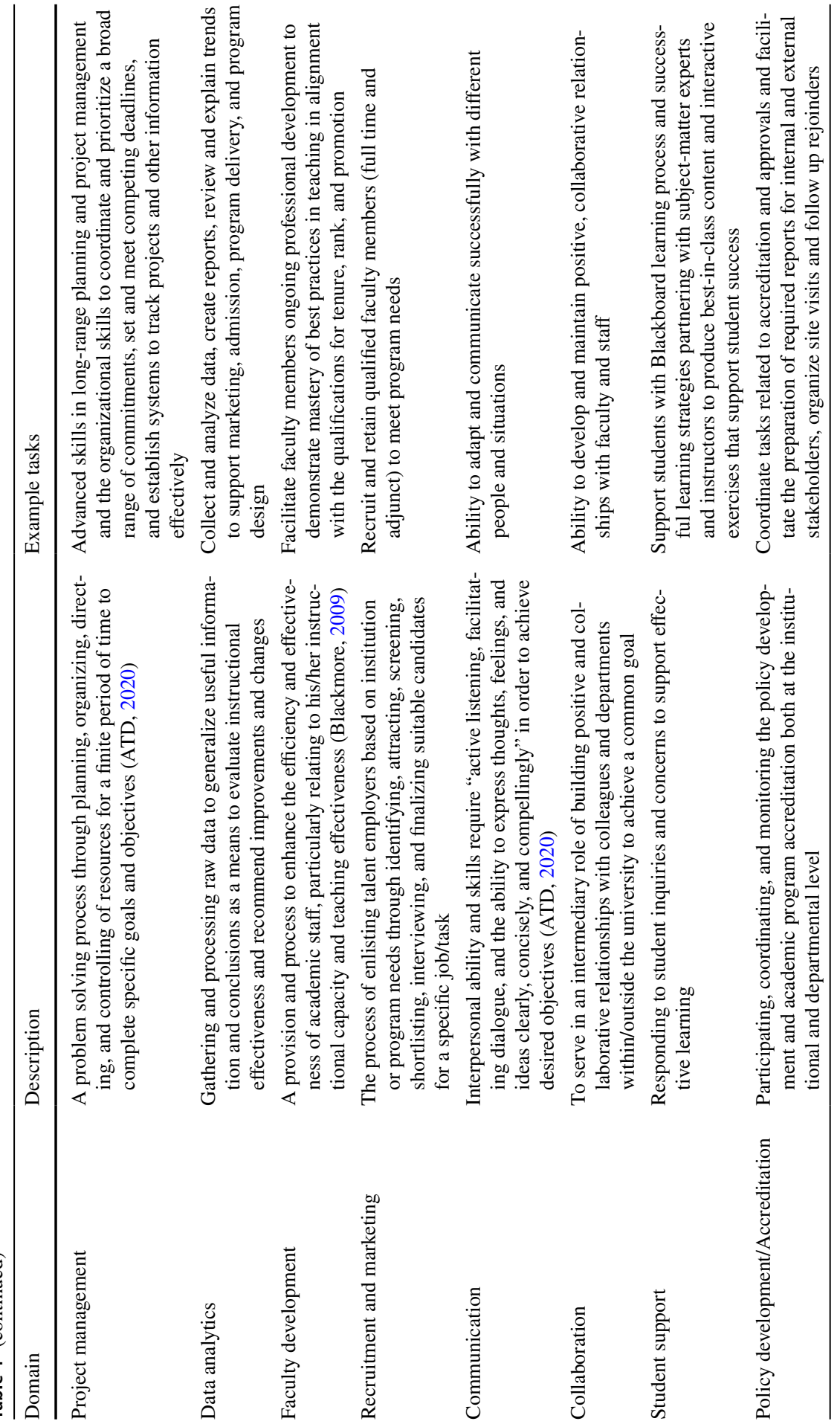




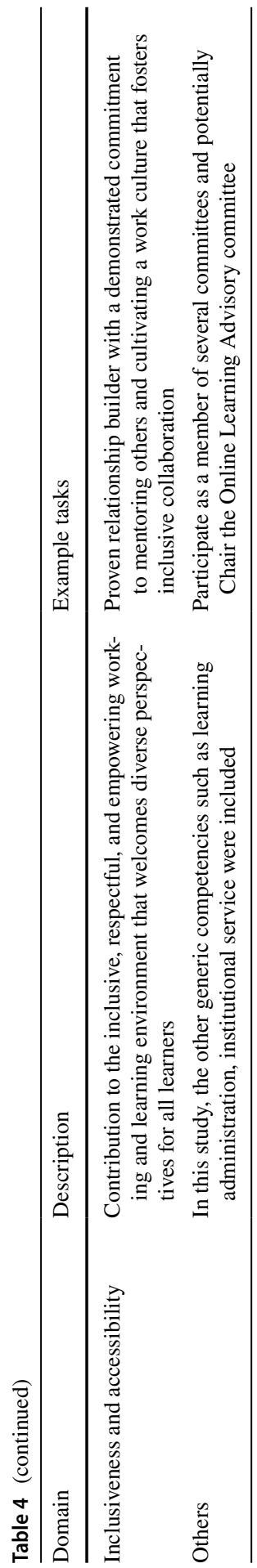


(21.09\%) and technologist (13.27\%). Also, designers $(\mathrm{M}=9.32)$, executives $(9.18)$ and directors (9.02) were required to be competent in the most number of competency domains.

\section{Learning and development competency domains}

For the twenty competency domains identified, the number of postings and percentages of total postings required each competency is included in Table 6. Collaboration $(89.12 \%)$, communication $(75.51 \%)$, content development $(71.43 \%)$, project management $(71.09 \%)$, and assessment and evaluation $(64.97 \%)$ were the most required competency domains in the job postings. The least required were policy development (10.88\%), mentoring and coaching (15.31\%), Inclusiveness and accessibility $(16.67 \%)$, recruitment and marketing (17.69\%), and data analytics $(19.39 \%)$.

\section{Learning and development roles and competency domains}

Each L\&D role was analyzed for the competency domains. Table 7 below gives us an overview of the various competency domain requirements in the job postings for the different roles. The frequency of competencies in the job postings by the job role is included in Table 7.

Table 8 includes the top five competency domains that were identified for an individual in each role to be competent. If two or more competencies are listed in the same box, each competency was advertised in an equal number of instances.

\section{Competencies for leadership roles and importance of collaboration and communication}

The executive and director leadership roles required the following competencies: leadership and people management, collaboration, assessment and evaluation, project

Table 5 Descriptive statistics by learning and development roles

\begin{tabular}{llclr}
\hline Role & $\begin{array}{l}\text { Number of post- } \\
\text { ings }\end{array}$ & Percentages & $\begin{array}{l}\text { Ave no. of competency } \\
\text { domains }\end{array}$ & SD \\
\hline Executive & 11 & 3.74 & 9.18 & 2.23 \\
Director & 62 & 21.09 & 9.02 & 2.52 \\
Manager & 16 & 5.44 & 7.94 & 2.93 \\
Specialist & 27 & 9.18 & 8.85 & 1.75 \\
Designer & 77 & 26.19 & 9.32 & 2.47 \\
Developer & 6 & 2.04 & 8.17 & 3.25 \\
Technologist & 39 & 13.27 & 8.03 & 2.44 \\
Coordinator & 24 & 8.16 & 8.71 & 2.80 \\
Associate/Assistant & 11 & 3.74 & 7.18 & 2.68 \\
Other & 21 & 7.14 & 7.38 & 2.84 \\
\hline
\end{tabular}


Table 6 Descriptive statistics by L\&D competency domains

\begin{tabular}{llll}
\hline No. & Competency domains & $\begin{array}{l}\text { Number } \\
\text { of post- } \\
\text { ings }\end{array}$ & Percentages \\
\hline D1 & Strategic Planning & 97 & 32.99 \\
D2 & Front-end Analysis & 65 & 22.11 \\
D3 & Theories and Frameworks & 139 & 47.28 \\
D4 & Instructional Design & 182 & 61.90 \\
D5 & Content Development & 210 & 71.43 \\
D6 & Facilitate Training & 187 & 63.61 \\
D7 & Assessment and Evaluation & 191 & 64.97 \\
D8 & Mentoring and Coaching & 45 & 15.31 \\
D9 & Tech/Infrastructure Support & 141 & 47.96 \\
D10 & Leadership \& People Management & 128 & 43.54 \\
D11 & Project Management & 209 & 71.09 \\
D12 & Data Analytics & 57 & 19.39 \\
D13 & Faculty Development & 137 & 46.60 \\
D14 & Recruitment and Marketing & 52 & 17.69 \\
D15 & Communication & 222 & 75.51 \\
D16 & Collaboration & 262 & 89.12 \\
D17 & Student Support & 104 & 35.37 \\
D18 & Policy Development, Accreditation & 32 & 10.88 \\
D19 & Inclusiveness and Accessibility & 49 & 16.67 \\
D20 & Other & 52 & 17.69 \\
\hline & & &
\end{tabular}

management, and communication competencies in their top five competency domains. The manager required project management and technology support and overlapping competencies requirement with the executive and director. Regarding specialist, designer, and developer roles, the top competencies emphasize instructional design, content development, project management, communication, and collaboration. Comparatively, among the nine roles examined, instructional design competencies were a requirement for four roles: designer, developer, technologist, and assistant/associate roles. Content development competency was required of four roles: designer, developer, coordinator, and assistant/associate.

We found that communication and collaboration are essential competencies for all nine learning and development roles examined in this study, as they were ranked within the top five rankings for each role. For the manager, communication and collaboration ranked the highest. For executives, specialists, technologists, associate/assistant, collaboration was also ranked high. These rankings show the importance of communication and collaboration in L\&D roles in higher education. 


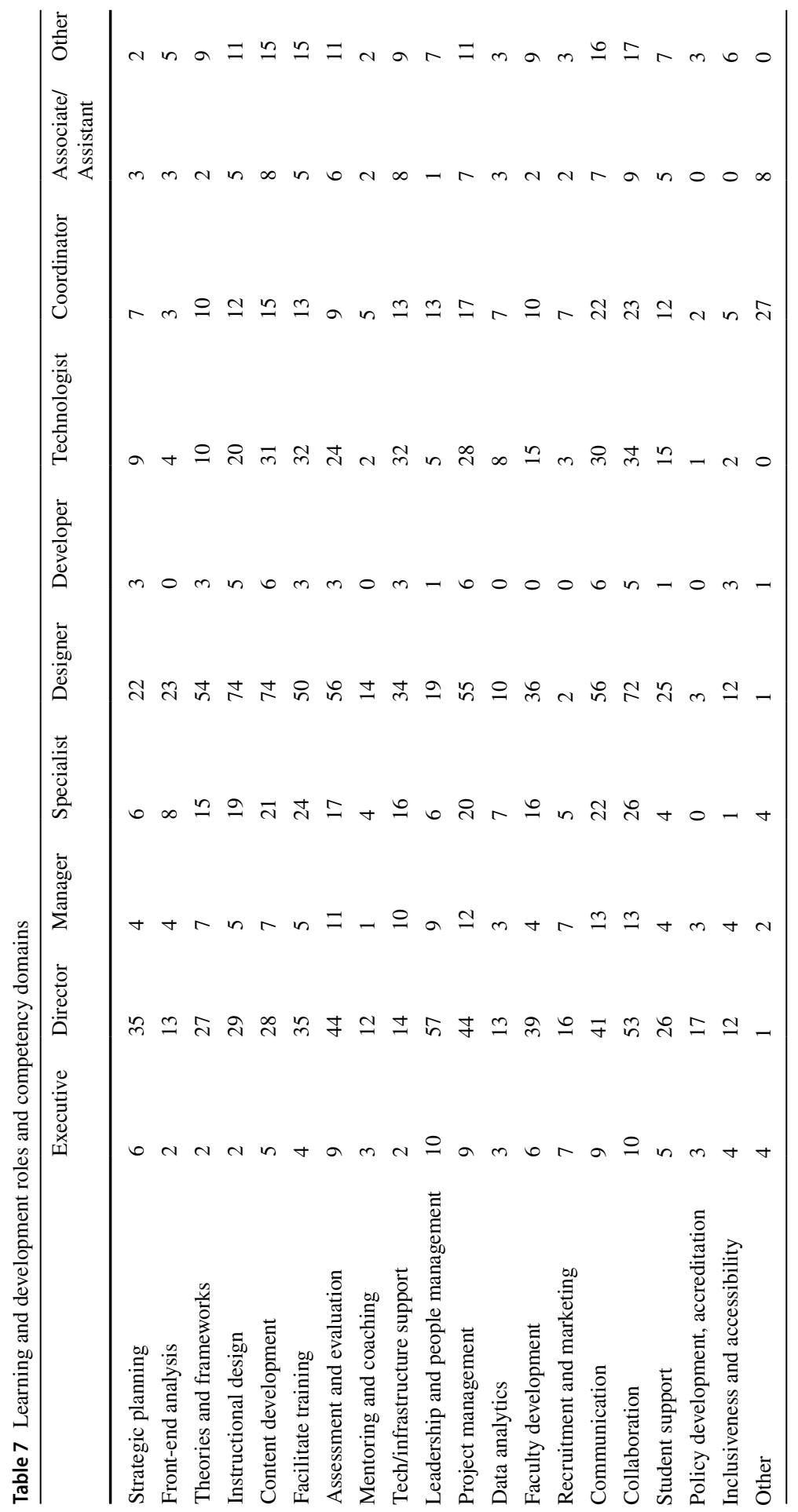




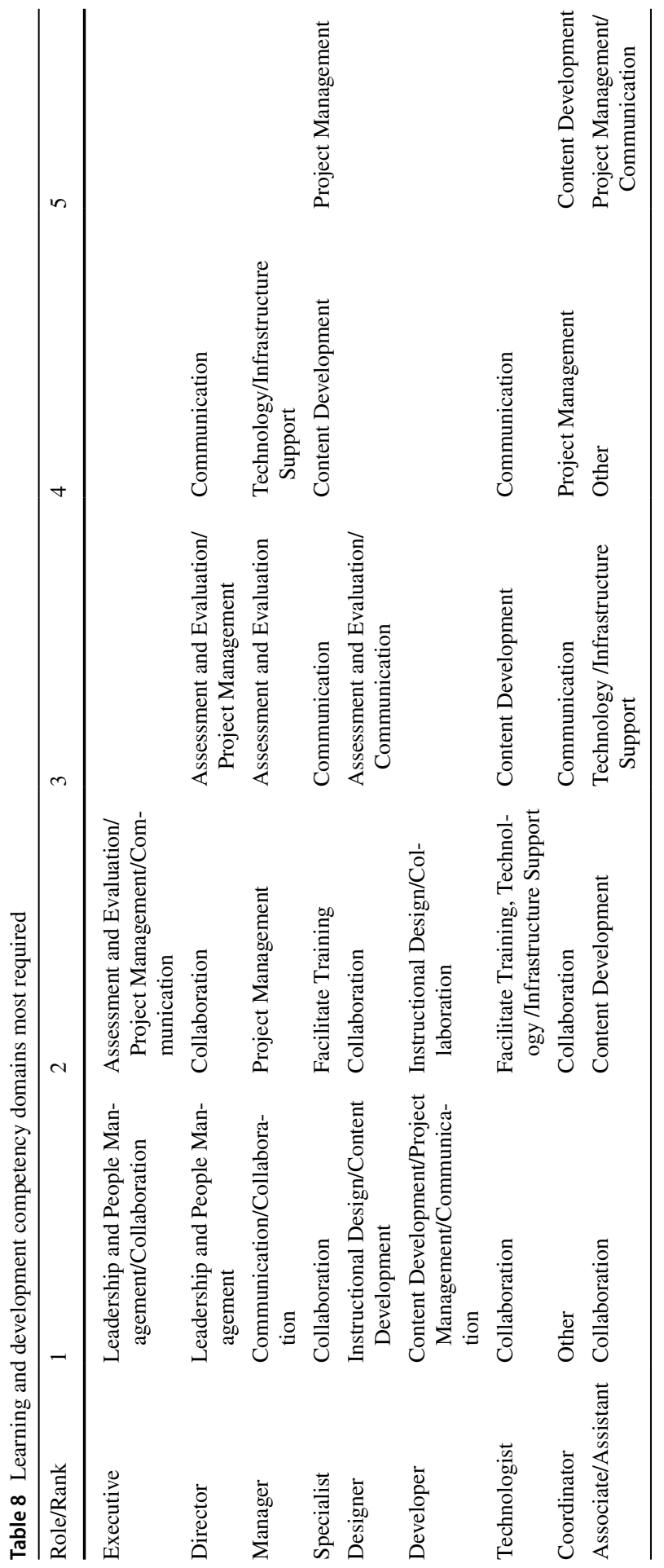


Table 9 Educational experience and job postings

\begin{tabular}{lll}
\hline Education & $\begin{array}{l}\text { Number of job post- } \\
\text { ings }\end{array}$ & Percentage \\
\hline High school diploma & 5 & 1.70 \\
Associate degree & 3 & 1.02 \\
Bachelors & 152 & 51.7 \\
Masters & 103 & 35 \\
Doctoral & 15 & 5.1 \\
Not listed & 16 & 5.4 \\
\hline
\end{tabular}

Table 10 Educational experience and job postings cross tab analysis

\begin{tabular}{lllllll}
\hline Roles & High school & Associate & Bachelors & Masters & Doctoral & Total \\
\hline Executive & 0 & 0 & 1 & 3 & 6 & 10 \\
Director & 0 & 0 & 16 & 32 & 9 & 57 \\
Manager & 0 & 0 & 12 & 2 & 0 & 14 \\
Specialist & 0 & 0 & 21 & 6 & 0 & 27 \\
Coordinator & 0 & 1 & 15 & 6 & 0 & 22 \\
Designer & 1 & 1 & 38 & 35 & 0 & 75 \\
Developer & 1 & 0 & 3 & 2 & 0 & 6 \\
Associate/Assistant & 3 & 1 & 2 & 4 & 0 & 10 \\
Technologist & 0 & 0 & 30 & 7 & 0 & 37 \\
Other & 0 & 0 & 14 & 6 & 0 & 20 \\
Total & 5 & 3 & 152 & 103 & 15 & 278 \\
\hline
\end{tabular}

\section{Educational experience}

The 294 job postings were also coded for the minimum required educational experience. About half of the postings required a Bachelor's degree (51.7\%), and about a third of the postings required a Master's degree (35\%). Some postings required either the bachelor's or master's degree qualifications. Those were coded as Bachelors because we considered the lowest degree required as the minimum requirement. About $16 \%$ of the postings did not provide an educational requirement. Educational experience required in job postings is included in Table 9.

A cross tab analysis was conducted to identify the degree required for the different roles (see Table 10). All the fifteen positions that required doctoral degrees were for executive and director positions. Manager, specialist, and technologist positions required either a bachelor's or master's degree. 


\section{Years of experience}

The 294 jobs were coded for years of experience. About $23.5 \%$ required three years' experience, while about $20.4 \%$ of the jobs required two years of experience. About a quarter of the jobs $(23.5 \%)$ did not provide experience requirements. When a range of years was listed in the job announcement, the lowest year in the range was included as the minimum requirement (Table 11).

While we did a cross-tab analysis of years of experience and roles, the data did not include any meaningful findings. For example, there were director postings requiring one year of experience and designer postings requiring seven years of experience.

\section{Discussion}

In this section below, we discuss the findings from this study.

\section{Varied and most advertised postings in learning and development}

There were ten different roles in learning and development in higher education, including the other category. Understanding the different competency domain requirements of these positions assists individuals and programs to prepare candidates for these roles successfully. A lot of educational programs and research focus solely on the instructional design role. Wang et al. (2020) examined 185 professional competencies for instructional designers by reviewing 1030 unique job announcements and analyzed by the different instructional setting. Ritzhaupt and Kumar (2015) examined competencies for instructional designers in higher education by interviewing eight instructional designers. While these are important and more in number, there are also several positions at the leadership level such as executive, director, and manager and at support roles such as coordinator, associate/assistant

Table 11 Years of experience and job postings

\begin{tabular}{llc}
\hline Years of experience & Number of postings & $\begin{array}{l}\text { Percent- } \\
\text { age of } \\
\text { jobs }\end{array}$ \\
\hline 1 year & 25 & 8.50 \\
2 years & 60 & 20.4 \\
3 years & 69 & 23.5 \\
4 years & 13 & 4.4 \\
5 years & 34 & 11.6 \\
6 years & 6 & 2.0 \\
7 years & 10 & 3.4 \\
8 years & 3 & 1.0 \\
10 years & 5 & 1.7 \\
Not mentioned & 69 & 23.5 \\
\hline
\end{tabular}


that have various positions and skills for which candidates could be better prepared. Klein and Kelly (2018) examined 393 job announcements for instructional designers and interviewed 20 instructional design project managers to identify competencies for instructional designers. Due to the various roles available, the promotion path in L\&D in higher education has to be made clear to the L\&D professionals (Prusko, 2020).

Designers were the most advertised position (26.19\%), followed by director $(21.09 \%)$ and technologist (13.27\%). Beirne and Romanoski (2018) discussed the growing demand for instructional designers in higher education as faculty face increased pressure to teach online and hybrid courses. In addition, administrators recognize that faculty need support from instructional designers who can assist in this transition. Our study confirmed this finding that designers were in demand. In addition to designers, technologists were also sought after in higher education, as indicated by the emerging needs of instructional technology integration in previous literature (Intentional Futures, 2016; Richey et al., 2001; Ritzhaupt \& Kumar, 2015; Sugrue et al., 2018). There is also a need for leaders to direct learning and development divisions.

\section{Competency domains most required}

Across the ten roles, including the other category, collaboration (89.12\%), communication $(75.51 \%)$, content development $(71.43 \%)$, project management $(71.09 \%)$, and assessment and evaluation (64.97\%) were the most required competency domains. Collaboration and communication competencies were required in most of the roles. Collaboration skills and communication skills have remained a vital competency across the roles for several years. Recently, Klein and Kelly (2018) found collaboration skills as a required competency among $75 \%$ of job postings and communication skills as required among $57 \%$ of the postings. Wang et al. (2021) found that collaboration skills, content development skills, oral and written communication skills, and ability to develop course materials, ability to create effective instructional products, ability to advise and consult with Subject Matter Expert were frequently occurring competencies in their job announcement analysis. Kang and Ritzhaupt (2015) and Ritzhaupt et al. (2010), a few years ago in their job announcement analysis, confirmed that both oral and written communication skills were key competencies for educational technologists. Our findings show the continued importance of communication and collaboration with the diverse stakeholders and team members involved in the learning and development jobs, which indicated the collaborative nature of learning and development for academic development in higher education (Sugrue et al., 2018).

Project Management competency was required in $71 \%$ of the postings. In most L\&D roles, these professionals also serve as the project managers, establish processes and strategies, and use technologies to complete tasks in a timely and effective manner (Gardner et al., 2017). In this study, Gardner et al. (2017) drew the relationship between instructional design phases and project management processes of initiating, planning, executing, and monitoring, and control and also 
discuss the importance of managing integration, scope, time, cost, quality, human resources, communication, risk, procurement, and stakeholders. Kline et al. (2020), when interviewing 13 educational technology project managers, found the following themes to emerge on project management knowledge, Project Team Management, Project Management Foundations and Practice, Project Scope and Needs Assessment, Project Scheduling \& Time Management, Project Stakeholder Engagement, Project Budgeting, and Cost Management and Project Resource Estimation and Management. Koszalka et al. (2013) have emphasized the projectbased nature of the field, and hence project management is a key aspect of practice for instructional designers. IBSTPI included a separate set of competencies for training managers who were in roles to manage training projects.

Executive and director leadership positions required leadership and people management competencies, project management, communication, collaboration and assessment, and evaluation competencies. Leadership and people management competencies were rated as the most required in the leadership potions, which indicate these leadership and management positions are responsible for faculty and staff development (Marshall et al., 2011; Mukherjee \& Singh, 1993). Doctoral programs preparing students for leadership roles in learning and development should prepare their students on these competencies.

Instructional design, facilitate training, and content development were required in several job postings. Instructional design competencies were required for Designer, Developer in the top 5 rankings, and content development competencies required for Specialist, Designer, Developer, Coordinator, Assistant/Associate in the top 5 rankings. These skills differentiate the learning and development professional from project managers or directors who may not be prepared to lead in learning and development roles. While facilitating training was required in $63 \%$ of the jobs, content development was required in $71 \%$ and instructional design was required in $61 \%$ of the jobs.

Drawing on these findings, we conceptualize four levels of learning and development roles in higher education contexts (See Fig. 1):

1. emphasizing the responsibilities of senior leadership, including executives, directors and managers focusing on leadership and people management, project management, assessment and evaluation

2. learning management, including managers and coordinators who are responsible for project management, technology/infrastructure support, and assessment and evaluation

3. the learning and development core professionals, including designers, developers, technologists, and specialists responsible for content development, instructional design, and technology/infrastructure support

4. finally, the learning and development support, including associates/assistants, are responsible for content development, project management, and technology/ infrastructure support. 
Communication and Collaboration skills were required of all the different learning and development roles.

\section{Educational experience, years and roles}

The cross-tab analysis identified that all fifteen postings that required doctoral degrees were for executive and director roles. These results show that to be a leader in $\mathrm{L} \& \mathrm{D}$, a doctoral degree is required. On the other hand, Manager, Specialist and Technologist roles required either Bachelors or Master's degrees. There were 152 postings that required a Bachelor's degree, while 103 postings required a Master's degree. Bachelor's degrees in Learning, Design and Technology are not as common as Master's degrees in the United States. This shows the need for more programs at the Bachelors's level to build the potential for students to acquire these jobs after their undergraduate degree. While educational degrees had some relationship to roles, years of experience data did not have any relationship.

\section{Limitations}

There are a few limitations to this job announcement analysis. We used only one higher education job board and analyzed postings from a short period of time. The postings were mainly from the United States, with a couple of exceptions from Canada. Therefore, these findings while they can be generalized to the US audience, they might have to be interpreted carefully for the rest of the world. The job postings were of different lengths. While some postings had a lot of detail, some did not. The length and amount of detail depended on who wrote the job posting, or it was a standard job posting from the human resources without the hiring team

\section{Learning and Development Roles and Competency Domains}
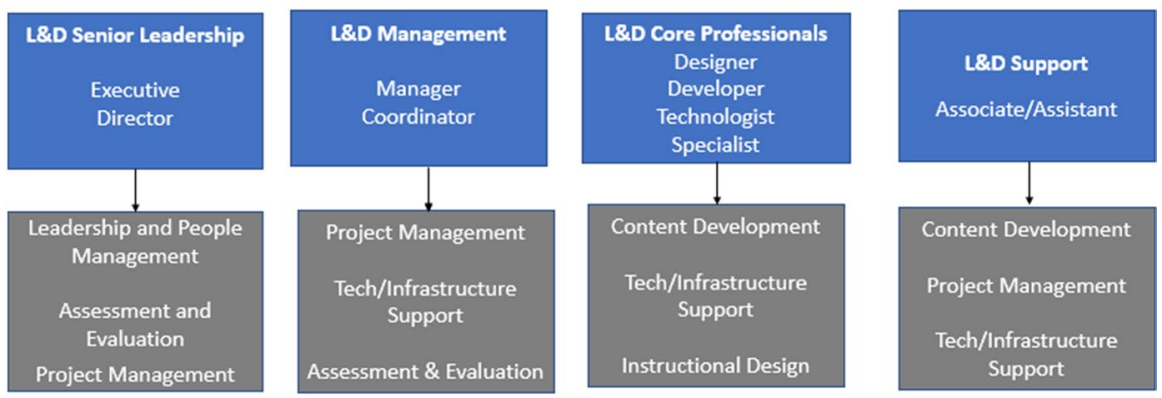

Communication and Collaboration

Fig. 1 Learning and development roles and domains 
involved. Finally, these postings were from 2019, and while these are important roles and domains for the next few years, this could change in the next decade and may have already changed substantially due to the Covid-19 pandemic. With the limitations identified, this study still has the potential to inform on the roles and competency domains in learning and development in higher education.

\section{Implications and future research}

The findings from this job announcement analysis have implications for students and job seekers who wish to obtain a job in learning and development in higher education, instructional design, and technology programs which prepares students for these roles, employers who hire for these positions, professional organizations who provide support for learning and development employees and for researchers who wish to study this topic.

Overall, the results reinforce the importance of communication and collaboration competencies along with project management competencies for all learning and development positions. For those in leadership roles, the importance of leadership and people management was also emphasized. It is important for students and job seekers to work towards the role they wish to apply for and be prepared with the competencies for that role. It is essential for credit-based programs and professional organizations to include these competencies in their curriculum and offerings for their students and participants. Also, this gives employers and hiring managers guidance on the competencies required for someone to be hired in this position. It also gives writers of future job postings guidance as to the competencies they may wish to see in new hires.

Finally, this study provides room for researchers to build on these findings to address both theory and practice questions for various roles in learning and development. This study primarily focused on positions in North America. There is still a need for research to examine job postings across the world. There is also room to use another methodology, such as surveying and interviewing professionals, and to add to the roles and competencies of learning and development professionals in higher education. Triangulating data from job announcements with survey and interview data will assist in analyzing needs and practice for various L\&D positions. In addition, future research is also important to examine curriculum offerings and professional development preparation for these various roles. Periodic analysis of competencies is essential due to the changes in the technologies and the expectations in these roles.

Funding There was no funding received for this project.

Declarations

Conflict of interest This is to acknowledge that there is no financial interest or benefit that has arisen from the direct applications of this research. 


\section{References}

AECT Standards, 2012 version. (2012). Retrieved August 2, 2020, from https://www.aect.org/docs/ AECTstandards2012.pdf.

APA PsycNet. (2020). Retrieved August 2, 2020, from https://doi.apa.org/doiLanding?doi=10.1037/ mgr0000102.

Association for Talent Development (2014). ATD competency model. Retrieved from https://www.td. org/certification/atd-competency-model.

Association for Talent Development (2020). Talent development glossary terms. Retrieved from https://www.td.org/glossary-terms.

Beirne, E., \& Romanoski, M. P. (2018). Instructional design in higher education: Defining an evolving field. In OLC outlook: An environmental scan of the digital learning landscape.

Bengtsson, M. (2016). How to plan and perform a qualitative study using content analysis. NursingPlus Open, 2, 8-14.

Blackmore, P. (2009). Conceptions of development in higher education institutions. Studies in Higher Education, 34(6), 663-676. https://doi.org/10.1080/03075070902785598

Burrus, J., Mattern, K. D., Naemi, B. D., \& Roberts, R. D. (2017). Establishing an international standards framework and action research agenda for workplace readiness and success. In J. Golubovich, R. Su, \& S. B. Robbins (Eds.), Building better students: Preparation for the workforce (pp. 303-338). Oxford University Press.

Cavalier, D., Gibbons, T., Halfond, J., Lambert, H., Novak, R., ... \& Wu, D. (n.d.). UPCEA hallmarks of excellence in professional and continuing education. Retrieved August 2, 2020, from https:// upcea.edu/wp-content/uploads/2017/03/UPCEA-Hallmarks-of-Excellence-in-Online-Leade rship.pdf.

Chao, I. T., Saj, T., \& Hamilton, D. (2010). Using collaborative course development to achieve online course quality standards. International Review of Research in Open and Distance Learning, 11(3), 106-126.

El Asame, M., \& Wakrim, M. (2018). Towards a competency model: A review of the literature and the competency standards. Educationand Information Technologies, 23(1), 225-236.

Gardner, J., Bennett, P. A., Hyatt, N., \& Stoker, K. (2017). Applying project management strategies in a large curriculum conversion project in higher education. Online Journal of Distance Learning Administration, 20(3).

Harnish, D., \& Wild, L. A. (1994). Mentoring strategies for faculty development. Studies in Higher Education, 19(2), 191-201. https://doi.org/10.1080/03075079412331382037

I4PL (2020). Institute for performance and learning. Retrieved from https://performanceandlearning. $\mathrm{ca} /$ page/I4PLAboutUs.

Intentional Futures (2016). Instructional design in higher education. Retrieved from https://intentiona lfutures.com/static/instructional-design-in-higher-education-report-5129d9d1e6c988c 25456 7f91f3ab0d2c.pdf.

International Board of Standards for Training, Performance and Instruction (2012). Instructional design competencies. Retrieved from https://ibstpi.org/download/?did=2705\&file $=0$.

Jacobs, S. (2017). L\&D executives seek learning architects. Retrieved from https://learningsolutio nsmag.com/articles/2443/ld-executives-seek-learning-architects.

Kang, Y., \& Ritzhaupt, A. D. (2015). A job announcement analysis of educational technology professional positions: Knowledge, skills, and abilities. Journal of Educational Technology Systems, 43(3), 231-256.

Klein, J. D., \& Kelly, W. Q. (2018). Competencies for instructional designers: A view from employers. Performance Improvement Quarterly, 31(3), 225-247. https://doi.org/10.1002/piq.21257

Kline, J., Kumar, S., \& Ritzhaupt, A. D. (2020). Project management competencies of educational technology professionals in higher education. The Journal of Applied Instructional Design, 9(3).

Koszalka, T. A., RussEft, D. F., \& Reiser, R. (2013). Instructional designer competencies: The standards (4th ed.). Information Age Publishing.

Kumar, S., \& Ritzhaupt, A. (2017). What do instructional designers in higher education reallydo? International Journal on E-Learning, 16(4), 371-393.

Lieberman, M. (2018). Learning engineers inch toward the spotlight. Retrieved August 2, 2020, from https://www.insidehighered.com/digital-learning/article/2018/09/26/learning-engineers-posechallenges-and-opportunities-improving. 
Marshall, S. J., Orrell, J., Cameron, A., Bosanquet, A., \& Thomas, S. (2011). Leading and managing learning and teaching in higher education. Higher Education Research \& Development, 30(2), 87-103. https://doi.org/10.1080/07294360.2010.512631

McDonald, J., \& Mayes, T. (2007). The changing role of an instructional designer in the implementation of blended learning at an Australian university. In Instructional design: Case studies in communities of practice (pp. 170-192). IGI Global.

Mukherjee, H., \& Singh, J. S. (1993). Staff development approaches in higher education: Learning from experience. Commonweath Secretariat.

O'Keefe (2018). The many hats of an instructional designer. Retrieved from https://www.td.org/insights/ the-many-hats-of-the-instructional-designer.

Richey R. C., (Ed.), Fields, D.C. \& Foxon, M. (2001). (With Roberts, R. C., Spannaus, T., \& Spector, J. M.). Instructional design competencies: The standards (3rd ed.). ERIC Clearinghouse on Information \& Technology. International Board of Standards for Training and Performance Improvement (ibstpi).

Ritzhaupt, A. D., \& Kumar, S. (2015). Knowledge and skills needed by instructional designers in higher education. Performance Improvement Quarterly, 28(3), 51-69.

Ritzhaupt, A. D., \& Martin, F. (2014). Development and validation of the educational technologist multimedia competency survey. EducationalTechnology Research and Development, 62(1), 13-33.

Ritzhaupt, A., Martin, F., \& Daniels, K. (2010). Multimedia competencies for aneducational technologist: A survey of professionals and job announcement analysis. Journal of Educational Multimedia and Hypermedia, 19(4), 421-449.

Sims, R. C., \& Koszalka, T. A. (2008). Competencies for the new-age instructional designer. Handbook of Research on Educational Communications and Technology, 3, 569-575.

Sugrue, C., Englund, T., Solbrekke, T. D., \& Fossland, T. (2018). Trends in the practices of academic developers: Trajectories of higher education? Studies in Higher Education, 43(12), 2336-2353. https://doi.org/10.1080/03075079.2017.1326026

The LPI Capability Map (2012). The LPI Capability Map-assessing essential skills in the new age of $L \& D$. Retrieved from https://www.thelpi.org/resources/capability-map/.

Van Rooij, S. W. (2012). The career path to instructional design project management: An expert perspective from the US professional services sector: Career path to instructional design project management. International Journal of Training and Development, 17(1), 33-53.

Wang, X., Chen, Y., Ritzhaupt, A., \& Martin, F. (2020). Examining competencies for the instructional design professional: An exploratory job announcement analysis. Presentation at the Association for Educational Technology Conference.

Wakefield, J., Warren, S., \& Mills, L. (2012). Traits, skills, and competencies aligned with workplace demands: What today's instructional designers need to master. In P. Resta (Ed.), Proceedings of society for information technology and teacher education international conference (pp. 3126-3132).

Publisher's Note Springer Nature remains neutral with regard to jurisdictional claims in published maps and institutional affiliations.

Florence Martin is a Professor in Learning, Design and Technology at the University of North Carolina Charlotte. Dr. Martin engages in research focusing on the effective design of instruction and integration of digital technology to improve learning and performance.

Yan Chen is a Postdoctoral Fellow in the Program of Organization, Information and Learning Sciences and the Department of Chemical and Biological Engineering at the University of New Mexico. Her research interests focus on computer-supported collaborative learning, learning sciences, instructional design, and educational equity for multicultural/multiethnic education.

Beth Oyarzun is a Clinical Assistant Professor at University of North Carolina at Charlotte. Prior to joining UNCC, she served as an instructional designer in the higher education environment for more than ten years. Her research interests are related to her teaching practice and she strives to identify effective strategies for online teaching and learning. 
Mark Lee is an Adjunct Senior Lecturer, School of Education Charles Sturt University and current President of the International Board of Standards for Training, Performance and Instruction. He is an educational technology and learning sciences researcher and practitioner. 